\title{
PENGARUH PEMBERIAN PEMBIAYAAN MURABAHAH TERHADAP NON PERFORMING FINANCING PADA BANK UMUM SYARIAH DI INDONESIA
}

\author{
Oleh: \\ Arim Nasim \\ (Dosen Program Studi Akuntansi Fakultas Pendidikan Ekonomi \& Bisnis UPI BHMN Bandung) \\ Cahyawati Ayu Pravitasari \\ (Alumni Program Studi Akuntansi Fakultas Pendidikan Ekonomi \& Bisnis UPI BHMN Bandung)
}

\begin{abstract}
Abstrak
Kegiatan bank dalam rangka menyalurkan dana yang ada tentunya memiliki beberapa risiko. Risiko yang umum terjadi adalah risiko macetnya pembiayaan yang telah disalurkan. Banyaknya pembiayaan macet merupakan salah satu indikasi bahwa bank dalam keadaan tidak sehat. Untuk itu, bank harus menjaga kualitas pembiayaannya. Penelitian ini bertujuan untuk mengetahui pengaruh dari pembiayaan murabahah terhadap Non Performing Financing (NPF) yang terjadi pada bank umum syariah di Indonesia pada periode 2005-2008. Penelitian ini menggunakan metode penelitian deskriptif analitis. Data penelitian diambil dari laporan keuangan bank umum syariah yang dilibatkan pada penelitian ini khususnya pada Catatan Atas Laporan Keuangan untuk tahun 2005-2008. Dalam penelitian ini yang menjadi variabel independen adalah pembiayaan murabahah dan yang menjadi variabel dependen adalah Non Performing Financing (NPF). Data dikumpulkan dengan teknik purposive sampling secara cross sectional dan time series. Untuk mengetahui normalitas data dilakukan uji KolmogorovSmirnov. Sedangkan untuk mengetahui berapa besar pengaruh variabel independen terhadap variabel dependen digunakan analisis korelasi Product Moment (Pearson). Terakhir, untuk mengetahui berapa besar perubahan variabel independen akan mempengaruhi perubahan variabel dependen maka dilakukan analisis Determinasi. Penelitian ini menunjukkan hasil bahwa didapat nilai koefisien korelasi sebesar $\mathbf{0 , 9 5 1}$. Dengan hasil seperti ini dapat diartikan bahwa hubungan antara kedua variabel penelitian adalah sangat kuat dengan arah hubungan berlawanan. Perubahan pembiayaan murabahah akan mempengaruhi perubahan Non Performing Financing sebesar $90,4 \%$. Hipotesis penelitian ini dapat diterima. Maka dapat diambil kesimpulan bahwa pembiayaan murabahah memiliki pengaruh yang sangat kuat terhadap Non Performing Financing pada bank umum syariah di Indonesia.
\end{abstract}

Kata Kunci: Pembiayaan Murabahah, Non Performing Financing (NPF)

Latar Belakang Penelitian 
Seperti umumnya sebuah bank, bank syariah juga menjalankan fungsi sebagai lembaga mediasi keuangan yaitu untuk menghimpun dan menyalurkan dana. Terdapat beberapa produk perbankan yang dikeluarkan bank syariah dalam rangka menjalankan kegiatan operasionalnya tersebut. Kegiatan bank syariah dalam rangka menghimpun dana di antaranya adalah berupa tabungan, giro, dan deposito syariah. Sedangkan untuk menjalankan fungsinya sebagai lembaga penyalur dana, bank syariah menyediakan beberapa bentuk pembiayaan seperti mudharabah dan musyarakah serta menjalankan bentuk jual beli yang berbasis murabahah.

Setiap bentuk penyaluran dana yang dilakukan oleh lembaga mediasi keuangan seperti bank ini tentunya memiliki risiko tersendiri atas terjadinya kemacetan dalam proses pengembalian dana kepada bank. Jika pada bank konvensional dikenal istilah kredit macet dengan Non Performing Loan (NPL) sebagai rasio yang menggambarkan seberapa besar kredit macet tersebut, maka pada bank syariah dikenal istilah pembiayaan bermasalah dengan Non Performing Financing (NPF) sebagai rasio yang menggambarkan seberapa besar terjadinya pembiayaan bermasalah.

Dalam hal ini, persentase pemberian pembiayaan dengan basis jual beli (murabahah) selalu berada di atas 57\% dan melihat adanya hubungan antara pemberian pembiayaan dengan risiko terjadinya pembiayaan bermasalah yang akhirnya akan berpengaruh terhadap Non Performing Financing, maka penulis bermaksud melakukan penelitian lebih jauh dengan judul "Pengaruh Pemberian Pembiayaan Murabahah Terhadap Non Performing Financing Pada Bank Umum Syariah di Indonesia”.

\section{Rumusan Masalah}

Berdasarkan latar belakang tersebut,masalah penelitian dapat dirumuskan sebagai berikut:

1. Bagaimana pemberian pembiayaan murabahah oleh bank umum syariah.

2. Bagaimana Non Performing Financing pada bank umum syariah.

3. Seberapa besar pengaruh pemberian pembiayaan murabahah terhadap Non Performing Finoncing.

\section{Kerangka Pemikiran}

Murabahah didefinisikan oleh Pandia et.al. (2005: 194) sebagai menjual suatu barang dengan harga asal (modal) ditambah dengan margin keuntungan yang disepakati.

Dalam praktiknya, pembiayaan dengan skema jual beli ini banyak diminati oleh nasabah sehingga proporsi pembiayaan yang diberikan oleh bank selalu didominasi oleh pembiayaan dengan skema murabahah. Dominasi penggunaan akad murabahah dalam pembiayaan tidak terlepas dari berbagai faktor, antara lain karakteristik pembiayaan murabahah yang return-nya dapat diperkirakan serta relatif lebih mudah dalam pengelolaan likuiditas bank. Selain itu, dari hasil Penelitian Kinerja Industri BPRS tahun 2002 juga diperoleh informasi bahwa perhitungan yang mudah dan sesuai permintaan nasabah merupakan latar belakang mengapa pembiayaan murabahah banyak disukai. 
Dalam menjalankan kegiatan operasionalnya bank tentu memiliki beberapa risiko. Salah satu risiko yang dapat terjadi pada bank adalah risiko bermasalahnya pengembalian kredit. Risiko dalam hal pengembalian juga dimiliki oleh bank syariah dengan adanya pengembalian pembiayaan yang bermasalah. Pengembalian pembiayaan yang bermasalah pada bank syariah ini dikenal dengan istilah non performing financing.

Dalam PSAK No. 31 (Revisi 2000) tentang Akuntansi Perbankan disebutkan bahwa kredit non performing pada umumnya merupakan kredit yang pembayaran angsuran pokok dan/atau bunganya telah lewat 90 (sembilan puluh) hari atau lebih setelah jatuh tempo, atau kredit yang pembayarannya secara tepat waktu sangat diragukan.

Timothy Koch dalam "Bank Management" (1995: 744) mengemukakan bahwa : "The problem categories are substandard, doubtful, and loss, with the probability of loss from the first to the third category". Berdasarkan uraian di atas dapat disimpulkan bahwa kualitas pembiayaan yang masuk dalam Non Performing Loan/Financing adalah kurang lancar (substandard), diragukan (doubtful), dan macet (loss) dengan risiko kerugian makin meningkat ke arah macet.

Penyebab timbulnya non performing financing sendiri dapat terbagi dalam 2 bagian. Timothy Koch membaginya menjadi faktor yang terkendali dan faktor yang tidak terkendali. Faktor yang terkendali berasal dari internal kondisi pelaku dalam bisnis bank syariah itu sendiri yaitu dari pihak bank maupun dari pihak nasabah. Sedangkan faktor yang tidak terkendali berasal dari luar/ekstern bank, umunya berkaitan dengan kebijakan pemerintah dan kondisi perekonomian baik nasional mapun internasional.

Maryanah dalam hasil penelitiannya menyebutkan bahwa dalam Islam pembiayaan yang dianjurkan adalah pembiayaan dengan skema bagi hasil. Sedangkan dalam praktiknya di lapangan pembiayaan murabahah dengan skema jual beli selalu mendominasi struktur pembiayaan.

Pembiayaan yang lebih dianjurkan oleh Islam adalah pembiayaan dengan skema bagi hasil yang biasanya digunakan sebagai modal dalam menjalankan sebuah kegiatan usaha. Hal ini disebabkan karena Islam sejatinya mengarahkan manusia untuk menjadi lebih produktif.

Pembiayaan dengan skema bagi hasil dapat dianalogikan dengan kredit produktif, sedangkan pembiayaan dengan skema jual beli dapat dianalogikan dengan kredit konsumtif. Fakta pada bank konvensional dan bank syariah pun serupa, bahwa pemberian kredit pada bank konvensional dan pemberian pembiayaan pada bank syariah lebih didominasi oleh kredit konsumtif dan pembiayaan dengan skema jual beli.

Di sisi lain, kita mengenal sebuah teori yang berbunyi "high return high risk" yang berarti bahwa di dalam return yang tinggi terdapat pula risk yang tinggi. Pembiayaan dengan skema jual beli pada bank syariah dinilai lebih menguntungkan dan lebih dapat menghasilkan return daripada pembiayaan dengan skema bagi hasil. Selain karena permintaan pembiayaan dengan skema ini lebih besar, yang dapat dibuktikan dengan proporsi penyaluran pembiayaan yang lebih mendominasi, juga dapat terjadi karena pembiayaan dengan skema jual beli lebih dapat dipastikan berapa margin yang akan diperoleh karena jumlah uangnya telah dinyatakan dan disepakati dengan debitur 
dalam akad jual beli. Sedangkan pada pembiayaan dengan skema bagi hasil meski telah diketahui pembagian persentase bagi hasilnya, tetap saja bank tidak dapat memastikan berapa jumlah keuntungan yang didapat oleh bank karena hal itu tergantung dari berapa besar keuntungan yang diperoleh oleh debitur setelah menjalankan usahanya. Dengan begitu dapat dikatakan bahwa pembiayaan dengan skema jual beli atau pembiayaan murabahah lebih dapat memberikan keuntungan (return) bagi bank. Namun di sisi lain, pembiayaan murabahah juga mengandung risiko pembiayaan. Proporsi pembiayaan murabahah yang selalu mendominasi struktur pembiayaan seperti saat ini dikhawatirkan akan membuat tingkat risiko pembiayaan bermasalah (NPF) yang muncul dari pembiayaan murabahah ini juga besar.

Dari pemaparan di atas, berpijak pada fakta bahwa pembiayaan dengan skema jual beli lebih mendominasi struktur pembiayaan pada bank syariah dan didasari konsep "high return high risk" penulis dapat menyatakan bahwa jumlah pembiayaan murabahah dengan skema jual beli akan mempengaruhi non performing financing sebagai sebuah bentuk risiko pembiayaan pada bank syariah.

\section{Metode Penelitian}

Metode penelitian yang digunakan dalam penelitian ini dilihat dari sudut level of explanation adalah metode penelitian deskriptif analitis yaitu metode penelitian yang digunakan untuk menggambarkan data dalam pemecahan masalah dengan mengumpulkan dan menyusun data kemudian menganalisis dan menginterpretasi data itu. Menurut analisis dan jenis data yang ada, penelitian ini termasuk dalam jenis penelitian kuantitatif karena data yang digunakan berbentuk data kuantitatif. Penelitian ini menggunakan analisis data sekunder yang berasal dari data laporan keuangan bank yang kemudian diolah untuk dianalisis dan diambil kesimpulannya.

Dalam penelitian ini variabel terdapat 2 yang dilibatkan yaitu variabel bebas (independen) yang disimbolkan dengan variabel $\mathrm{X}$ dan variabel terikat (dependen) yang disimbolkan dengan variabel Y. Menurut Sugiyono (2008: 59), "variabel bebas adalah merupakan variabel yang mempengaruhi atau yang menjadi sebab perubahannya atau timbulnya variabel dependen (terikat)". Sedangkan pengertian dari variabel terikat menurut Sugiyono (2008: 59), "variabel terikat merupakan variabel yang dipengaruhi atau yang menjadi akibat, karena adanya variabel bebas".

Dalam penelitian ini yang menjadi variabel bebas (variabel $X$ ) adalah pembiayaan murabahah sedangkan yang menjadi variabel terikat (variabel $Y$ ) adalah Non Performing Financing.

Populasi dalam penelitian ini adalah seluruh bank umum syariah yang ada di Indonesia beserta laporan keuangannya dari semua tahun. Bank umum syariah yang ada di Indonesia sampai akhir tahun 2008 terdapat 5 bank.

Data yang menjadi sampel pada penelitian ini adalah data laporan keuangan 3 bank umum syariah yang ada sejak tahun 2005-2008. Dari 5 bank umum syariah yang ada saat ini, 2 bank tidak dapat dilibatkan dalam penelitian karena baru menjadi bank umum syariah pada tahun 2008. Alasan mengapa diambil tahun laporan 2005-2008 adalah karena salah satu sampel yang digunakan baru menjadi bank umum syariah pada 
pertengahan tahun 2004 sehingga laporan keuangan bank tersebut yang mencakup tahun buku selama 1 tahun penuh baru ada pada tahun 2005.

Data yang digunakan dalam penelitian ini adalah data bank umum syariah yang ada pada tahun 2005-2008 secara cross sectional dan time series. Cross sectional yaitu studi satu tahap yang datanya berupa beberapa subjek pada waktu tertentu, sedangkan time series yaitu studi yang data penelitiannya berupa data rentetan waktu. Penelitian ini menggunakan kombinasi dari kedua metode tersebut untuk mendapatkan data yang diperlukan.

Tahapan yang dilakukan dalam menganalisis data dengan statistik deskriptif adalah sebagai berikut:

1. Menghitung jumlah pembiayaan murabahah yang disalurkan oleh bank-bank umum syariah dari tahun 2005-2008 yang kemudian disajikan dalam bentuk persentase.

2. Menghitung tingkat Non Performing Financing (NPF) setiap bank, yaitu dengan membandingkan antara jumlah pembiayaan murabahah bermasalah yang diperoleh dari penjumlahan pembiayaan kurang lancar, pembiayaan diragukan, dan pembiayaan yang macet dengan jumlah pembiayaan yang diberikan.

Untuk dapat melakukan analisis selanjutnya dengan statistik inferensial, perlu dilakukan penghitungan nilai rata-rata (mean) dari masing-masing variabel dengan menggunakan statistik deskriptif. Adapun rumus nilai rata-rata (mean) adalah sebagai berikut.

$M e_{(x, y)}=\frac{\sum\left(x_{;}, y\right)}{n}$

di mana,

Me = mean (rata-rata hitung)

$\sum \quad=$ jumlah

$x_{i} \quad=$ nilai $x$ dari ke 1 hingga ke $n$

$y_{i} \quad=$ nilai $y$ dari ke 1 hingga ke n

= banyak tahun

Setelah menghitung kedua variabel tersebut maka selanjutnya akan dilakukan analisis dengan menggunakan statistik inferensial. Statistik inferensial sendiri yaitu teknik statistik yang digunakan untuk menganalisis data sampel dan hasilnya diberlakukan untuk populasi (Sugiyono, 2008:207). Teknik statistik inferensial yang digunakan dalam penelitian ini akan digunakan untuk meneliti pengaruh antara pemberian pembiayaan murabahah dengan non performing financing pada sampel. Namun, hasil yang didapat pada penelitian terhadap sampel ini tidak akan digeneralisasi karena teknik sampling yang digunakan adalah sampling purposive.

Tahapan analisis data dengan menggunakan statistik inferensial yang dilakukan dalam penelitian ini adalah sebagai berikut :

1. Uji normalitas data

Untuk tahap pertama penelitian ini perlu dilakukan uji normalitas sebaran data. Hal ini diperlukan karena semua perhitungan statistik parametrik menggunakan asumsi adanya sebaran data yang normal. Sugiyono (2008:239) menyatakan bahwa :

Jurnal Akuntansi Riset, Prodi Akuntansi UPI, Vol. 1, No. 2 
"Pengujian hipotesis dalam penelitian ini menggunakan statistik parametris karena data yang akan diujikan berbentuk ratio. Karena akan menggunakan statistik parametris, maka data pada setiap variabel harus diuji terlebih dulu normalitasnya. Bila data setiap variabel tidak normal, maka pengujian hipotesis tidak bisa menggunakan statistik parametris".

Uji normalitas data dilakukan dengan uji Kolmogorov-Smirnov. Untuk mempermudah dalam melakukan penghitungan secara statistik, maka semua analisis yang dilakukan dalam penelitian ini akan diolah dengan bantuan software statistik SPSS 16.0 for Windows.

2. Analisis Korelasi Product Moment (Pearson)

Setelah data yang didapat diolah sehingga dapat dianalisis, dilakukan analisis Korelasi dengan menggunakan metode Product Moment (Pearson). Rumus Korelasi Product Moment adalah sebagai berikut :

$$
r=\frac{n \sum x y^{*}-\sum x \sum y^{z}}{\sqrt{\left.n \sum x^{2}-\left(\sum x\right)^{n}\right)\left(n \sum y^{2}-\left(\sum y\right)^{2}\right)}}
$$

di mana :

$r=$ koefisien korelasi

$x=$ variabel independen (pembiayaan murabahah)

$y=$ variabel dependen (non performing financing)

$n=$ jumlah sampel

Nilai $\mathbf{r}$ (koefisien korelasi) yang didapat ini akan memperlihatkan kuat atau tidaknya variabel X mempengaruhi variabel Y. Sugiyono (2008:250) memberikan pedoman untuk memberikan interpretasi koefisien korelasi sebagai berikut.

\section{Pedoman Untuk Memberikan Interpretasi Koefisien Korelasi}

3. Koefisien Determinasi

\begin{tabular}{|c|c|}
\hline Interval Koefisien & Tingkat Hubungan \\
\hline $0,00-0,199$ & Sangat Rendah \\
\hline $0,20-0,399$ & Rendah \\
\hline $0,40-0,599$ & Sedang \\
\hline $0,60-0,799$ & Kuat \\
\hline $0,80-1,000$ & Sangat Kuat \\
\hline
\end{tabular}

Setelah diketahui nilai koefisien korelasi (r) yang memperlihatkan derajat atau kekuatan korelasi antar variabel, maka akan dihitung koefisien determinasi (Kd) yang akan dapat memperlihatkan berapa persen variasi variabel $\mathrm{X}$ akan mempengaruhi variabel $\mathrm{Y}$. Adapun rumus koefisien determinasi adalah sebagai berikut :

$$
\text { Kid }=r^{2} \times 1000
$$

di mana :

$\mathrm{Kd}=$ Koefisien Determenasi 
$r \quad=$ Nilai Koefisien Kolerasi

Nilai $K_{d}$ berada antara 0 sampai $1\left(0 \leq K_{d} \leq 1\right)$ :

- Jika nilai $K_{d}=0$, berarti tidak ada pengaruh variabel independen (X) terhadap variabel dependen (Y).

- Jika nilai $K_{d}=1$, berarti variasi (naik-turunnya) variabel dependen $(Y)$ adalah $100 \%$ dipengaruhi oleh variabel independen $(\mathrm{X})$.

- Jika nilai $K_{d}$ berada antara 0 sampai $1\left(0 \leq K_{d} \leq 1\right)$, maka besarnya pengaruh variabel independen adalah sesuai dengan nilai $K_{d}$ itu sendiri, dan selebihnya berasal dari faktor-faktor lain.

\section{Hasil Penelitian}

\section{Kondisi Pembiayan Murabahah}

Dengan melihat data-data yang ada pada bank umum syariah dan juga data statistik perbankan syariah yang dikeluarkan Bank Indonesia selaku bank sentral, maka dapat diketahui bahwa seluruh bank umum syariah yang beroperasi di Indonesia saat ini lebih banyak menyalurkan dana yang dimilikinya melalui skema murabahah atau jual beli. Meskipun dari segi persentase mengalami naik turun, namun dari segi jumlah nominal dana yang disalurkan cenderung terus mengalami peningkatan dari tahun ke tahun.

Dari data yang digunakan dalam penelitian ini maka dapat diketahui bahwa bank umum syariah yang banyak menyalurkan pembiayaan kepada nasabahnya adalah Bank Syariah Mandiri. Data tersebut menunjukkan bahwa selama kurun waktu tahun 2005 sampai dengan tahun 2008 Bank Syariah Mandiri telah menyalurkan dana ratarata sebesar Rp. 9.076.803.236.000 pertahunnya. Dari jumlah tersebut rata-rata sebesar Rp. 5.031.933.518.000 atau 55,44\% dari total pembiayaan disalurkan melalui skema murabahah. Hal ini melampaui pembiayaan rata-rata yang dapat disalurkan oleh Bank Muamalat yaitu sebesar $\mathrm{Rp}$. 7.039.539.497.000 per tahun di mana rata-rata 50,62\% pembiayaan tersebut atau sebesar $R$ p. 3.563.230.894.000 per tahun disalurkan melalui skema murabahah. Hal ini dapat terjadi karena jumlah nominal dana yang disalurkan melalui pembiayaan bergantung kepada berapa besar modal yang dimiliki oleh masingmasing bank.

Namun bila kita lihat lebih jauh, maka kita akan mengetahui bahwa persentase rata-rata penyaluran pembiayaan murabahah kedua bank umum syariah yang telah dibahas sebelumnya masih jauh lebih kecil dibandingkan dengan Bank Syariah Mega Indonesia. Jika Bank Muamalat dan Bank Syariah Mandiri selama periode 2005 sampai dengan 2008 masing-masing menyalurkan rata-rata 50,62\% dan 55,44\% pembiayaannya melalui skema murabahah, maka Bank Syariah Mega Indonesia dalam kurun waktu yang sama telah menyalurkan rata-rata $90,51 \%$ pembiayaannya melalui skema murabahah. Hal ini mungkin terjadi mengingat melalui skema apa pembiayaan akan disalurkan bergantung pada kebijakan dari manajemen masing-masing bank umum syariah. Selain itu, perkembangan jumlah pembiayaan yang disalurkan dengan skema murabahah yang sangat pesat dimungkinkan mengingat mudahnya persyaratan dalam mengajukan pembiayaan.

Jurnal Akuntansi Riset, Prodi Akuntansi UPI, Vol. 1, No. 2 


\section{Kondisi Non Performing Financing}

Tingginya persentase pembiayaan yang disalurkan dengan skema murabahah dibandingkan melalui skema lain nyatanya telah mampu menekan laju pertumbuhan non performing financing. Selama tahun 2005 sampai dengan 2008 rata-rata non performing financing yang terjadi adalah sebesar $3,73 \%$. Hal ini membuktikan bahwa minimnya risiko yang terkandung dalam pembiayaan murabahah dapat mengendalikan laju non performing financing meskipun dari segi persentase maupun jumlah nominal pembiayaan yang disalurkan sangat besar.

Namun bila dilihat kondisi masing-masing bank umum syariah, tampaknya bank umum syariah yang ada masih harus terus berusaha mengendalikan terjadinya non perfroming financing. Pasalnya, dari 3 bank umum syariah yang dilibatkan dalam penelitian ini, hanya 2 bank yang dapat dikategorikan sehat dilihat dari non performing financing yang dicapai. Sedangkan 1 bank lainnya, meskipun dari tahun ke tahun cenderung mengalami penurunan, namun non performing financing yang dicapai masih berada di atas standar yang diperbolehkan oleh Bank Indonesia yaitu masih di atas $5 \%$. Bank tersebut adalah Bank Syariah Mandiri dengan capaian 5,51\%. Dengan capaian seperti itu, maka bank umum syariah tersebut masih belum dapat dikatakan sehat jika dilihat dari tingkat non performing financing yang dicapai.

Tingginya tingkat non performing financing ini di antaranya disebabkan oleh tingginya pembiayaan bermasalah yang terus meningkat dari tahun ke tahun. Tingkat non performing financing di atas batas maksimum yang ditetapkan Bank Indonesia ini mengindikasikan adanya penurunan kolektibilitas pembiayaan yang telah tersalurkan oleh bank umum syariah.

Untuk Bank Muamalat yang capaian non performing financing-nya berada pada kisaran $4,79 \%$, tetap harus berhati-hati terhadap tingkat non performing financing-nya. Capaian tersebut masih dianggap riskan dan mendekati batas maksimum yang diperbolehkan Bank Indonesia untuk tingkat non performing financing.

Di sisi lain, Bank Syariah Mega Indonesia sebagai bank yang dapat dikategorikan sehat harus mempertahankan kinerjanya dalam menjaga kesehatan bank dengan tetap menekan pertumbuhan non performing finoncing. Tingkat non performing financing Bank Syariah Mega Indonesia dinilai sangat baik karena berada di bawah standar yang diperbolehkan oleh Bank Indonesia yaitu hanya sebesar 0,89\% rata-rata per tahun selama periode 2005-2008.

\section{Pengaruh Pemberian Pembiayaan Murabahah terhadap Non Performing Financing}

Hasil penelitian ini menyatakan bahwa antara pembiayaan murabahah yang disalurkan oleh bank umum syariah dan non performing financing yang terjadi pada bank umum syariah terdapat koefisien korelasi dengan nilai -0,951. Hal ini menunjukkan bahwa terdapat pengaruh yang sangat kuat antara pembiayaan murabahah dengan non performing financing dengan arah yang berlawanan. Secara praktis dapat 
dikatakan bahwa jika terjadi kenaikan penyaluran pembiayaan murabahah maka akan dikuti dengan terjadinya penurunan non performing financing. Sebaliknya, jika terjadi penurunan penyaluran pembiayaan murabahah, maka akan terjadi kenaikan non performing financing pada bank umum syariah.

Bank yang memiliki kelebihan dana (excess liquidity) cenderung menetapkan kebijakan penyaluran pembiayaan yang ekspansif dengan membuat target berapa jumlah pembiayaan yang harus dicapai dalam kurun waktu tertentu. Keharusan pencapaian target tersebut cenderung mendorong bank untuk menempuh langkahlangkah yang lebih agresif dalam penyaluran pembiayaan. Hal tersebut dapat mengakibatkan bank tidak lagi selekif dalam memilih calon debitur dan kurang menerapkan prinsip kehati-hatian. Akhirnya, hal tersebut akan mengakibatkan naiknya jumlah pembiayaan bermasalah. Dengan kata lain, semakin besar pembiayaan yang disalurkan maka akan semakin besar pula kemungkinan non performing financing akan terjadi.

Namun demikian, hasil penelitian ini bertentangan dengan teori tersebut. Hal ini dapat disebabkan oleh banyak hal. Dua di antaranya adalah karena praktik penyaluran pembiayaan yang ekspansif tetap diiringi dengan penerapan prinsip kehati-hatian secara konsisten oleh bank umum syariah serta niat baik debitur bank umum syariah untuk melakukan kegiatan muamalah secara sehat. Dengan demikian, berapa besarpun jumlah pembiayaan murabahah yang diberikan akan mengandung risiko terjadinya kemacetan yang kecil.

Menurut pemikiran penulis, terdapat satu alasan di luar alasan secara finansial yang dapat mempengaruhi mengapa meningkatnya pemberian pembiayaan murabahah dapat membuat non performing financing mengalami penurunan. Pertimbangan lain yang lebih kuat dalam memilih bank adalah faktor ketaatan pada ketentuan muamalah yang telah diatur dalam Islam. Dalam memilih bank dan melakukan kegiatan ekonomi di dalamnya tidak lagi dilakukan hanya untuk mencari keuntungan semata, namun juga sebagai suatu bentuk ibadah. Hal ini memperlihatkan bahwa kesadaran masyarakat Indonesia yang mayoritas beragama Islam untuk mematuhi ketentuan muamalah telah lebih baik. Faktor kepatuhan bermuamalah ini tentunya juga akan mempengaruhi sikap seorang debitur terhadap kewajiban yang dimilikinya, dalam hal ini adalah kewajiban untuk membayar utangnya kepada bank. Dengan kata lain, faktor kepatuhan bermuamalah debitur bank syariah membuat meningkatnya pembiayaan murabahah berpengaruh negatif terhadap non performing financing. Meskipun demikian, penulis kira hal ini perlu diteliti lebih jauh lagi.

Hasil penelitian lebih lanjut mengenai berapa besar perubahan penyaluran pembiayaan murabahah akan mempengaruhi terjadinya non performing financing dengan menghitung nilai koefisien determinasi menghasilkan angka sebesar 0,904. Dari nilai tersebut selanjutnya dapat diambil kesimpulan bahwa perubahan pada non performing financing dipengaruhi oleh perubahan penyaluran pembiayaan murabahah sebesar $90,4 \%$. Sedangkan sebesar $9,6 \%$ sisanya dipengaruhi oleh faktor-faktor lain yang tidak penulis teliti dalam penelitian ini. 
Saat ini hampir seluruh bank umum syariah yang ada melakukan penyaluran dana kepada nasabah dengan skema murabahah. Selain karena persyaratan dan proses yang mudah, pembiayaan dengan skema ini dinilai memiliki risiko yang kecil dan memiliki proyeksi margin yang jelas bagi bank karena disebutkan dalam akad jual beli berapa besar margin yang diperoleh. Sedangkan skema lain seperti mudharabah dan musyarakah dinilai memiliki risiko yang lebih besar bagi bank dan proyeksi margin yang masih belum dapat dipastikan karena margin yang diterima oleh bank pada skema mudharabah dan musyarakah bergantung pada berapa besar margin yang diperoleh nasabah setelah melakukan usaha.

Hasil penelitian ini memperlihatkan bahwa peningkatan jumlah pemberian pembiayaan murabahah dari tahun ke tahun tidak perlu dikhawatirkan akan menimbulkan risiko terjadinya non performing financing yang semakin tinggi. Bahkan minimnya risiko yang terkandung dalam pembiayaan murabahah ini mampu menekan laju pertumbuhan non performing financing.

Simpulan

Berdasarkan hasil penelitian dan pembahasan yang telah dipaparkan sebelumnya, maka penulis dapat mengambil simpulan bahwa:

1. Dari data yang ada dapat dilihat penyaluran pembiayaan murabahah cenderung fluktuatif. Pembiayaan murabahah tertinggi disalurkan oleh Bank Syariah Mega Indonesia dengan capaian hingga $95,07 \%$ pada tahun 2008. Peningkatan persentase penyaluran pembiayaan murabahah tertinggi dicapai Bank Syariah Mega Indonesia pada tahun 2006, dari sebelumnya berada pada angka $57,66 \%$ pada tahun 2005 naik $35,99 \%$ menjadi $93,65 \%$ pada tahun 2006 . Hal ini mungkin terjadi mengingat melalui skema apa pembiayaan akan disalurkan bergantung pada kebijakan dari manajemen masing-masing bank umum syariah. Selain itu, perkembangan jumlah pembiayaan yang disalurkan dengan skema murabahah yang sangat pesat dimungkinkan mengingat mudahnya persyaratan dalam mengajukan pembiayaan.

2. Non Performing Financing yang dicapai oleh ketiga bank umum syariah selama periode 2005-2008 ini cukup flukuatif. Non performing financing tertinggi dicapai pada tahun 2006 oleh Bank Syariah Mandiri sebesar 7,13\%. Nilai non performing financing Bank Syariah Mandiri ini berada di atas batas wajar yang ditetapkan oleh Bank Indonesia sebesar 5\%. Dengan demikian, dapat dikatakan bahwa bank tersebut dalam kondisi yang tidak sehat. Di sisi lain, bank umum syariah yang mencapai non performing financing paling rendah adalah Bank Syariah Mega Indonesia pada tahun 2005 yang hanya mencapai $0,50 \%$.

3. Pembiayaan murabahah memiliki pengaruh yang sangat kuat terhadap adanya non performing financing dengan arah yang berlawanan. Dari hasil tersebut dapat diartikan bahwa jika jumlah pembiayaan murabahah meningkat maka akan menyebabkan non performing financing mengalami penurunan, dan sebaliknya.

\section{Saran}

Jurnal Akuntansi Riset, Prodi Akuntansi UPI, Vol. 1, No. 2 
Berdasarkan hasil penelitian yang telah dilakukan, penulis dapat mengajukan saran sebagai berikut :

1. Hendaknya pihak bank umum syariah perlu mengadakan sosialisasi dan pendekatan personal kepada nasabah dan debiturnya untuk membentuk sebuah pemahaman bersama bahwa kegiatan ekonomi yang dilakukan antara bank dan nasabah atau debitur didasarkan pada hukum muamalah dalam Islam. Jika pemahaman ini dapat ditanamkan baik pada bank, nasabah atau pun debitur tentunya masing-masing pihak mengerti apa saja hak dan kewajibannya. Dengan demikian, salah satu tujuan yang diharapkan dapat dicapai adalah debitur tetap memenuhi kewajibannya meskipun dalam keadaan ekonomi yang menurun. Hal ini akan membuat tingkat non performing financing semakin turun.

2. Bagi peneliti selanjutnya yang tertarik untuk melakukan penelitian sejenis, hendaknya meneliti beberapa atau seluruh faktor yang mempengaruhi non performing financing agar dapat diketahui faktor mana yang lebih berpengaruh terhadap non performing financing. Di samping itu, penelitian tentang seberapa besar pengaruh ketaatan bermuamalah yang telah penulis sampaikan sebelumnya hendaknya diteliti lebih jauh.

\section{DAFTAR PUSTAKA}

Bank Indonesia. (2007-2008). Statistik Perbankan Syariah Januari 2007-Desember 2008. Jakarta : Bank Indonesia.

Donna, Doddy Roesmara. (2007). "Perbankan Syariah (1)". Buletin Ekonomika dan Bisnis Islam. Edisi 1I/V 8 Jumadil Ula 1428 H/25 Mei 2007. p. 1.

Faud, Moh. Ramli, dan M. Rustan DM. (2005). Akuntansi Perbankan. Yogyakarta : Graha Ilmu.

Hamidi, M. Luthfi. (2003). Jejak-Jejak Ekonomi Syariah. Jakarta: Senayan Abadi Publishing.

Ikatan Akuntan Indonesia. (2007). Standar Akuntansi Keuangan. Jakarta: Salemba Empat.

Jogiyanto. (2007). Metodologi Penelitian Bisnis Salah Kaprah dan Pengalamanpengalaman. Yogyakarta : BPFE.

Koch, Timothy.W. (1995). Bank Management $3^{\text {rd }}$ Edition. New Jersey: Dryden Press.

Maryanah. (2008). "Faktor-Faktor yang Mempengaruhi Pembiayaan Bagi Hasil di Bank Syariah Mandiri". EKSIS Jurnal Ekonomi Keuangan dan Bisnis Islami Vol. 4 No.1 Januari-Maret 2008/Muharram-Rabiul Awal 1429 H. p. 2.

Pandia, Frianto, et al. (2005). Lembaga Keuangan. Jakarta : PT. Rineka Cipta.

Saidi, Zaim. dan Imran N. Hosein. (2003). Tidak Islamnya Bank Islam Kritik Atas Perbankan Syariah. Jakarta : Pustaka Adina.

Siamat, Dahlan. (2004). Manajemen Lembaga Keuangan. Jakarta: Lembaga Penerbit Fakultas Ekonomi Universitas Indonesia.

Sudjana. (2000). Statistika Untuk Ekonomi dan Niaga 1. Bandung : Tarsito.

Sudjana. (1997). Statistika Untuk Ekonomi dan Niaga II. Bandung : Tarsito.

Jurnal Akuntansi Riset, Prodi Akuntansi UPI, Vol. 1, No. 2 
Sugiyono. (2008). Metode Penelitian Bisnis. Bandung : Alfabeta.

Supramono dan Intiyas Utami. (2004). Desain Proposal Penelitian. Yogyakarta : Penerbit Andi.

Suyatno, Thomas., et.al. (2007). Kelembagaan Perbankan. Jakarta : Gramedia Pustaka Utama.

Trihendardi, Cornelius. (2009). Step by Step SPSS 16 Analisis Data Statistik. Yogyakarta : Penerbit Andi.

Undang-Undang Republik Indonesia Nomor 10 Tahun 1998 Tentang Perubahan atas Undang-Undang Nomor 7 Tahun 1992 Tentang Perbankan.

Yuliana. (2007). "Pengaruh Risiko Pembiayaan Murabahah dan Tingkat Suku Bunga Kredit terhadap Tingkat Marjin Pada Produk Pembiayaan Murabahah". Skripsi. Bandung : Fakultas Ekonomi Universitas Padjadjaran. 